\title{
Odd cause for acute anicteric hepatitis in a woman with systemic lupus erythematosus
}

\author{
Cyriac Abby Philips, ${ }^{01}$ Rajaguru Paramaguru, ${ }^{2}$ Glaxon Alex $^{3}$
}

${ }^{1}$ The Liver Unit, Ernakulam Medical Centre, Kochi, Kerala, India

${ }^{2}$ Pathology, PVS Memorial Hospital Ltd, Cochin, Kerala, India

${ }^{3}$ Rheumatology, Center for Arthritis and Rheumatism, Kochi, Kerala, India

\section{Correspondence to} Dr Cyriac Abby Philips, abbyphilips@gmail.com

Accepted 15 March 2019

Check for updates

(C) BMJ Publishing Group Limited 2019. No commercial re-use. See rights and permissions. Published by BMJ.

\footnotetext{
To cite: Philips CA,

Paramaguru R, Alex G. BMJ

Case Rep 2019:12:e229230.

doi:10.1136/bcr-2019-

229230
}

\section{DESCRIPTION}

A 50-year-old woman, diagnosed with systemic lupus erythematosus (SLE) for 4 years and in remission on azathioprine and tacrolimus, without complementary and alternative medication intake, presented with severe lumbosacral radicular pain associated with difficulty in walking for 1 week. On evaluation elsewhere, she was found to have mild focal protrusion of lumbar intervertebral disc for which conservative management was started. She later developed altered behaviour with drowsiness, lasting for a few minutes without convulsions. Blood investigations revealed grossly abnormal liver tests with normal serum total bilirubin, alkaline phosphate and gamma-glutamyl transpeptidase associated with raised aspartate transaminase 1886 (normal <38 IU/L), alanine transaminase $2032(<40 \mathrm{IU} / \mathrm{L})$ and international normalised ratio 1.6. Tests for viral hepatitis $\mathrm{A}, \mathrm{B}, \mathrm{C}$ and $\mathrm{E}$ were negative, total serum $\operatorname{IgG}$ was within normal limits and autoantibody panel for liver diseases was unremarkable. Imaging of the liver revealed only hepatomegaly. Given multiple systems involvement, a percutaneous liver biopsy was performed after the correction of coagulation abnormality with fresh frozen plasma $(10 \mathrm{~mL} / \mathrm{kg}) .{ }^{1}$ Liver histopathology showed distorted architecture due to irregular 'punched-out' haemorrhagic necrosis (figure 1A) of hepatocytes with minimal neutrophilic inflammation (figure 1B), few hepatocytes showed intranuclear ground glass appearance (figure 1C) in the presence of terminal hepatic venular necrosis, features that were typical of herpeshepatitis. IgM antibody for Herpes simplex (HSV) type 1 was positive. Azathioprine and tacrolimus were switched over to intravenous corticosteroids, intravenous acyclovir was initiated and continued for 5 days after which oral antiviral was continued for a total of 28 days. Liver tests normalised in 7 days and clinical improvement was completed in 2 weeks. Low dose step-up approach to immunosuppression was thereafter reinstated. Liver involvement in the acute setting in SLE patients is a diagnostic challenge. Drug-induced liver injury, acute viral hepatitis, acute vascular diseases of the liver, opportunistic infections and rarely autoimmune hepatitis are close differential diagnosis. ${ }^{2}$ Acute hepatitis due to HSV is uncommon and seldom reported in patients with SLE. It is a potential cause of fatal acute liver failure in both immunocompromised and immunocompetent patients and completely reversible, if recognised early. A high degree of suspicion, even in the absence of skin lesions but with multiple system involvement as seen in our patient (encephalitis, lumbosacral neuralgia and hepatitis), along with early liver biopsy and serological evaluation can help confirm the diagnosis and dramatically improve survival. Early initiation of intravenous acyclovir is life saving. ${ }^{3}$ Liver biopsy shows classical features of haemorrhagic necrosis with minimal inflammation, ground-glass intranuclear viral inclusion (Cowdry B) with or without the typical '3-M's' (multinucleation, chromatin margination and nuclear moulding) or eosinophilic intranuclear inclusion surrounded by a clear halo (Cowdry A). ${ }^{4}$ Prospective data on secondary prophylaxis for recurrent acute HSV infection lacks in the literature, although some authors have used life-long antiviral prophylaxis for patients reinstated on strong immunosuppression. This practice however, may lead to acyclovir resistance. ${ }^{3}$ In immunosuppressed patients, strong clinical suspicion for potentially treatable causes for acute hepatitis must be sought early on during evaluation, for initiation of potential life-saving measures.
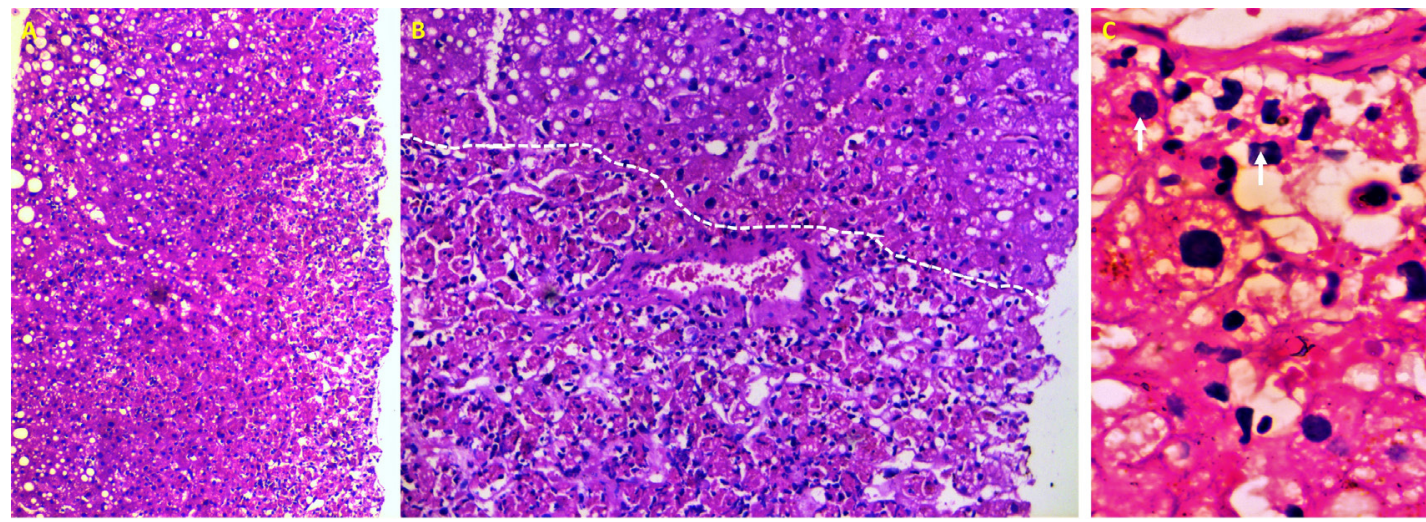

Figure 1 Liver biopsy findings showing: (A) irregular and punched-out areas of haemorrhagic hepatocyte necrosis $(H \& E, \times 10),(B)$ clearly demarcated (dotted line) haemorrhagic necrotic areas with minimal neutrophilic inflammation $(H \& E, \times 20)$ and $(C)$ few hepatocytes showing nucleomegaly with ground glass intra-nuclear inclusions (arrows, oil immersion on $\mathrm{H} \& \mathrm{E}, \times 40)$. 


\section{Learning points}

- Herpes simplex virus (HSV) is an uncommon but potentially reversible cause for severe acute hepatitis in immunosuppressed patients.

- Strong clinical suspicion based on early high liver enzymes levels, multiple system involvement and early decision on performing liver biopsy improves patient outcomes.

- Presence of ground glass or eosinophilic nuclear inclusions and haemorrhagic hepatocyte necrosis with minimal inflammation are typical features on liver biopsy that help in early recognition.

Contributors CAP: wrote the manuscript. RP: provided pertinent pathology images. GA: revised the manuscript. All authors finalised the submitted version of the manuscript
Funding The authors have not declared a specific grant for this research from any funding agency in the public, commercial or not-for-profit sectors.

Competing interests None declared.

Patient consent for publication Obtained.

Provenance and peer review Not commissioned; externally peer reviewed.

\section{REFERENCES}

1 Patel IJ, Davidson JC, Nikolic B, et al. Consensus guidelines for periprocedural management of coagulation status and hemostasis risk in percutaneous image-guided interventions. J Vasc Interv Radiol 2012;23:727-36.

2 Levitsky J, Duddempudi AT, Lakeman FD, et al. Detection and diagnosis of herpes simplex virus infection in adults with acute liver failure. Liver Transp/ 2008; 14:1498-504.

3 Natu A, luppa G, Packer CD. Herpes simplex virus hepatitis: a presentation of multiinstitutional cases to promote early diagnosis and management of the disease. Case Reports Hepatol 2017;2017:1-5.

4 Chan AWH, Quaglia A, Haugk B, et al. Viral liver disease. Springer New York, NY: Atlas of Liver Pathology, 2014:85-103.

Copyright 2019 BMJ Publishing Group. All rights reserved. For permission to reuse any of this content visit https://www.bmj.com/company/products-services/rights-and-licensing/permissions/

BMJ Case Report Fellows may re-use this article for personal use and teaching without any further permission.

Become a Fellow of BMJ Case Reports today and you can:

- Submit as many cases as you like

- Enjoy fast sympathetic peer review and rapid publication of accepted articles

- Access all the published articles

Re-use any of the published material for personal use and teaching without further permission

For information on Institutional Fellowships contact consortiasales@bmjgroup.com

Visit casereports.bmj.com for more articles like this and to become a Fellow 